\title{
Precision agriculture applied to soybean: Part I - Delineation of management zones
}

\author{
Eduardo Leonel Bottega ${ }^{1 *}$, Daniel Marçal de Queiroz ${ }^{2}$, Francisco de Assis de Carvalho Pinto ${ }^{2}$, \\ Cristiano Márcio Alves de Souza ${ }^{3}$, Domingos Sárvio Magalhães Valente ${ }^{2}$
}

\author{
${ }^{1}$ Federal University of Santa Maria, Cachoeira do Sul City, Rio Grande do Sul State, Brazil \\ ${ }^{2}$ Federal University of Viçosa, Agricultural Engineering Department, Viçosa city, Minas Gerais State, Brazil \\ ${ }^{3}$ Federal University of Grande Dourados, Faculty of Agricultural Sciences, Dourados City, Mato Grosso do Sul \\ State, Brazil
}

*Corresponding author: bottega.elb@gmail.com

\begin{abstract}
The knowledge of the correlation between the spatial variability of soil attributes and crop yield is necessary for defining precision agriculture practices. The objective of the present study was to characterize soybean yield by mapping the spatial variability of the soil texture and apparent electrical conductivity for the delineation of management zones. The study was conducted in a field located in the Brazilian Savannah. The soybean yield, soil texture, and apparent electrical conductivity of an Oxisol were analyzed and mapped. The management zones were generated using the data from the spatial dependence of the mapped variables. The soil map that correlated best with the yield map was determined. The management zones were defined using the apparent soil electrical conductivity with the highest Kappa coefficient (0.30) for the soybean yield. The results demonstrate the potential utility of apparent soil electrical conductivity map for agriculture precision.
\end{abstract}

Keywords: Site-specific management, No-tillage, Soil apparent electrical conductivity, Crop yield, Oxisol.

\section{Introduction}

Crop production in the Brazilian Savannah is dominated by the use of modern technologies, including the efficient use of fertilizers, management of pests and diseases, use of cultivars adapted to climate change and the quality of soil and use of no-till systems. No-till system is one of the topsoil conservation technologies that has resulted in the optimization of the quality and production potential of the soil in the region. The natural spatial variability of the soil and the additional variability due to crop management lead to a greater variability in soil physicochemical attributes, both vertically and horizontally. Thus, the knowledge of spatial variability of the soil attributes and its correlation with the crop yield is essential for the precise management of soil (ZanãoJúnioret al., 2010).

Crop yield can be optimized through the knowledge of the spatial variability of soil and plant attributes (Amado et al., 2009). The delineation of management zones for soil conservation is a potential technique for the management of the spatial variability of crops and soils (Dalchiavon et al., 2012). In addition to optimizing the use of fertilizers, this technique reduces costs and impacts on the environment. According to Rodrigues Junior et al. (2011), a management zone is defined as a sub-region with the homogenous combination of yield-limiting factors for which a single rate of specific crop input can be applied uniformly.

Considering the spatial variability of the soil attributes, the delineation of management zones allows differentiated management, primarily the soil amendment and fertilization
(Fuet al., 2010). Due to both high temporal and spatial variability, some of the soil attributes are inappropriate in defining management zones.

According to Zanão Junior et al. (2007), the spatial variability pattern for each soil attribute can vary with some attributes having a higher spatial dependence than others. The differences in the spatial dependency require more samples for certain attributes than for others. In addition to the spatial variability, certain soil attributes also exhibit temporal variability. The utilization of soil attributes with low variability over time is a key to the successful delineation of management zones. With the consistent soil attributes, the management zones will also be more stable over time.

The relationship between soil texture attributes and crop yield is well-known and has been studied extensively. In general, soil texture has low temporal variability, making it a potential candidate for delineating management zones. Nevertheless, the mapping of the spatial variability of apparent soil electrical conductivity (ECa) has been the most extensively studied alternative in the recent years.

Studies have shown correlations between apparent electrical conductivity and various chemical attributes of soil (Moral et al., 2010; Morari et al., 2009; Rodríguez-Pérez et al., 2011). Compared to spatial attribute mapping, ECa mapping is fast and inexpensive means of mapping soils for determination of attributes in the laboratory. Owing to the reliability and ease of measurement, ECa has become widely 
used indirect estimator of variability in an agricultural field (Corwin and Lesch, 2003).

Management zone delineation techniques in agricultural production have been adopted to optimize inputs, increase crop productivity, and reduce environmental impacts. The use of soil chemical attributes, which involve a labor-intensive collection and expensive analysis, can negatively affect this technique, making it inconvenient at the agricultural holding scale (King et al., 2005; McCormick et al., 2009; Zhang et al., 2010). The present study investigated the potential use of soil texture analysis owing to their low temporal variability for the generation of management zones. The objective of this study was to delineate management zones to best characterize soybean yield by mapping the spatial variability of the soil texture and the apparent electrical conductivity of the soil.

\section{Results and Discussion}

\section{Descriptive statistical analysis of soil properties}

The descriptive statistics of the data are represented in Table 1. The ECa values varied between 2.74 and $19.31 \mathrm{mS} \mathrm{m}^{-1}$, the same range was observed by Machado et al. (2006). The highest coefficient of variation was observed for the coarse sand (CS) content, while the lowest one was observed for the soil moisture content (MC).

Apparent soil ECa, coarse sand (CS) and fine sand (FS) contents were significantly correlated with the yield (Table 2 ). The soybean yield negatively correlated with the apparent soil ECa. This soil attribute also showed a significantly negatively correlation with CS content.

A high correlation between ECa and clay content (CC) has been reported in some studies (Molin and Castro, 2008); however, in other studies (Morari et al., 2009; Serrano et al., 2010), including the present one, this correlation was either very low or remain undetectable. The $\mathrm{CC}$ soil attribute was significant and negatively correlated with the other soil particle fractions (CS, FS, and slit content). According to Souza et al. (2004), soil particle fractions display inverse behavior (when one increases the other decreases), particularly in regard to their distribution; fractions were measured as a percentage.

\section{Spatial variability analysis of soil attributes}

The parameters for the experimental semivariograms were adjusted to the theoretical semivariance models of the studied attributes and are presented in Table 3. The Gaussian model was found to be the best-fit model for semivariogram of ECa, CS, and FS. This model is the representative of the phenomena that have strong continuity for the short distances or a slight variation as a function of observation distances. Except for silt content, the $\mathrm{R}^{2}$ values of the attributes were found to be equal to or greater than 0.95 . The highest RSS - a statistic that calculates the soil portion, not explained by the model - was observed for FS and the lowest for soil moisture (MC).

The greatest range observed for ECa was $664 \mathrm{~m}$. The silt had the lowest range value $(117 \mathrm{~m})$. The variogram range was used as the maximum number of data points in each neighborhood radius in the kriging process. The interpolation process provides more reliable estimates when the variogram ranges are greater (Coráet al., 2004). Figure 1 illustrates the spatial distribution of the soybean yield, apparent soil ECa, and MC, CS, FS, S and clay contents of the soil.

\section{Analysis of management zone maps based on ECa and the soil attribute maps}

Kappa coefficients are shown in Table 4. The highest value of kappa coefficient was 0.3 , and found between the management zone map based on the yield and that based on ECa when classified into two classes. The management zone map was generated using the ECa soil attribute based on the selection criteria of the management zones, firstly on the classification of the kappa coefficient, then on the number of the classes in the map, and finally on the numerical magnitude of the kappa coefficient (Fig. 2). The test also indicated a significant difference between this map and the other maps grouped into two classes (Table 4).

\section{Analysis of management zones and yield data}

In the present study, the management zones were generated using the results of the soil texture analysis, separately or combined only when three classes were included in the analysis. The map with two management zones based on the apparent soil $\mathrm{ECa}$ was in the greatest agreement with the management zone map based on the yield data, with a kappa coefficient of 0.30 , which is low but still higher than zero. This kappa coefficient was different from the other coefficients calculated from the maps generated with two classes using combinations of soil texture data.

Several studies have demonstrated the relationship between $\mathrm{ECa}$ and crop yield. In the present study, the relationship between ECa and crop yield was significant, with a Pearson's correlation coefficient of -0.18 , confirming the results reported by Alcântara et al. (2012), who studied the correlation between soybean yield and ECa under a no-till system in the Brazilian Savannah (-0.25). Likewise, Kitchen et al. (2005) and Valente (2010) demonstrated that the combined use of ECa and altitude generated better results in the delineation of management zones for appropriate use of fertilizer and lime recommendations. As the slope of our study area was less than $5 \%$, the altitude was not considered in the analysis. Alves et al. (2013) found a significant difference between the mean values of soybean yield in the two zones of a distinguished field based on ECa.

The map of management zones based on $\mathrm{ECa}$ measurements exhibited greater kappa coefficient with the yield map because of the high correlation with physicochemical attributes of the soil. ECa is influenced by the combination of physicochemical properties including salts, mineralogy of clay, moisture content and temperature of the soil (Brevik et al., 2006). Although this attribute is also influenced by soil moisture, i.e., the regions with higher moisture content have higher values of ECa. King et al. (2005) have demonstrated that the spatial pattern remains relatively stable with only changes in the magnitude.

\section{Optimum number of management zones}

Figure 3 shows the plots of the Fuzzy Performance Index (FPI) and the Modified Partition Entropy (MEP) versus a number of classes in the cluster analysis for the generation of management zones from soybean yield and ECa. The FPI and MPE decline with the increasing number of classes of soybean yield. An opposite pattern was found for grouping the ECa values. The best FPI and MPE values observed for the delineation of management zones based on soybean yield were 0.3276 and 0.3215 , respectively. The zones generated based on the ECa values presented an FPI value of 0.2071 and an MPE value of 0.2668 . Very similar FPI and MPE 
Table 1. Descriptive statistics of the measured soil attributes and crop yield.

\begin{tabular}{|c|c|c|c|c|c|c|c|c|}
\hline \multirow{2}{*}{ Attribute } & \multicolumn{8}{|c|}{ Statistical parameters } \\
\hline & Mean & Median & Minimum & Maximum & $\mathrm{s}^{(8)}$ & $\mathrm{CV}(\%)^{(9)}$ & $\mathrm{Cs}^{(10)}$ & $\mathrm{Ck}^{(11)}$ \\
\hline $\mathrm{Y}^{(1)}$ & $2,302.75$ & $2,345.26$ & $1,225.06$ & $3,244.49$ & 298.44 & 12.96 & -0.35 & 0.85 \\
\hline $\mathrm{ECa}^{(2)}$ & 6.19 & 5.94 & 2.74 & 19.31 & 2.13 & 34.44 & 2.24 & 9.29 \\
\hline$M C^{(3)}$ & 24.46 & 24.99 & 15.75 & 28.02 & 2.23 & 9.14 & -1.88 & 3.89 \\
\hline $\mathrm{CS}^{(4)}$ & 4.42 & 3.45 & 2.52 & 15.24 & 2.79 & 62.99 & 2.66 & 6.32 \\
\hline $\mathrm{FN}^{(5)}$ & 11.25 & 9.69 & 5.42 & 33.47 & 5.45 & 48.42 & 2.62 & 6.70 \\
\hline$S^{(6)}$ & 15.87 & 16.25 & 3.45 & 38.29 & 5.28 & 33.29 & 0.35 & 2.59 \\
\hline $\mathrm{CC}^{(7)}$ & 68.45 & 70.06 & 36.38 & 87.06 & 7.39 & 10.80 & -1.25 & 3.09 \\
\hline
\end{tabular}

$\left(\right.$ dag kg $\left.{ }^{-1}\right) ;{ }^{8}$ Standard deviation; ${ }^{9}$ Coefficient of variation; ${ }^{10}$ Skewness coefficient; ${ }^{11}$ Kurtosis coefficient.

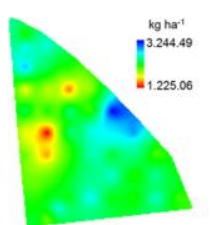

Yield

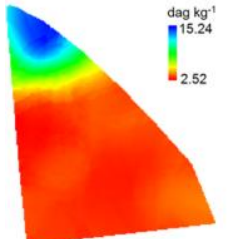

Coarse sand

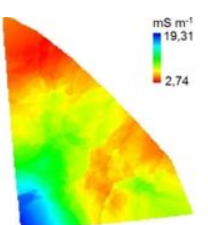

$\mathrm{ECa}$

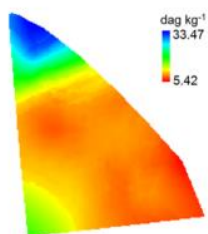

Fine sand

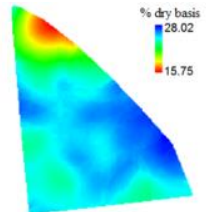

Moisture

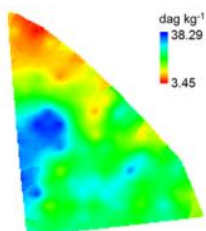

Silt

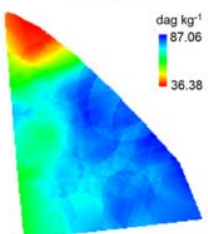

Clay

Fig 1. Thematic map of the spatial distribution of soybean yield, apparent electrical conductivity, moisture content, and soil grain size.

Table 2. Pearson's correlation coefficients between the soil attributes analyzed and crop yield.

\begin{tabular}{|c|c|c|c|c|c|c|}
\hline Attributes & $\mathrm{Y}$ & $\mathrm{ECa}$ & $\mathrm{CS}$ & FS & $\mathrm{S}$ & $\mathrm{CC}$ \\
\hline $\mathrm{Y}^{1}$ & 1.00 & & & & & \\
\hline $\mathrm{ECa}^{2}$ & $-0.18 *$ & 1.00 & & & & \\
\hline $\mathrm{CS}^{3}$ & $0.22 *$ & $-0.25^{*}$ & 1.00 & & & \\
\hline $\mathrm{FS}^{4}$ & $0.20 *$ & -0.13 & $0.90 *$ & 1.00 & & \\
\hline$S^{5}$ & -0.14 & 0.15 & $-0.41 *$ & $-0.34 *$ & 1.00 & \\
\hline $\mathrm{CC}^{6}$ & -0.08 & 0.08 & $-0.66^{*}$ & $-0.73 *$ & $-0.33^{*}$ & 1.00 \\
\hline
\end{tabular}
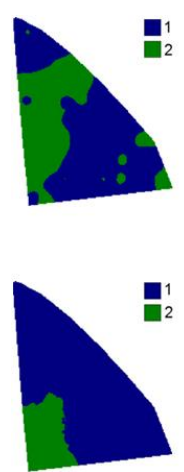

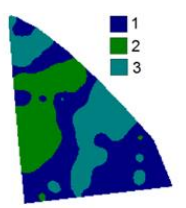

(A)
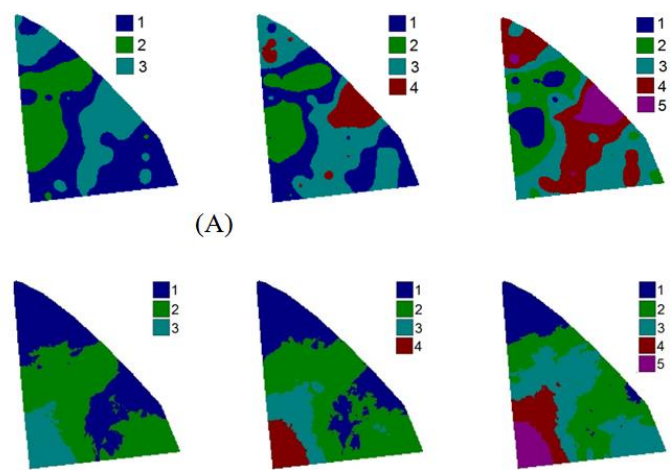

(B)

Fig 2. Management zones generated from the soybean yield (A) and apparent soil electrical conductivity (B) for different numbers of classes. 
Table 3. Theoretical semivariogram parameters adjusted to the empirical semivariance of the soil attribute studied and the crop yield.

\begin{tabular}{|c|c|c|c|c|c|c|}
\hline \multirow{2}{*}{ Attributes } & \multicolumn{6}{|c|}{ Geostatistical parameters } \\
\hline & Model & $a^{(8)}$ & $\mathrm{C}_{0}+\mathrm{C}^{(9)}$ & $\mathrm{C}_{0}^{(10)}$ & $\operatorname{RSS}^{(12)}$ & $\mathrm{R}^{2(13)}$ \\
\hline$Y^{(1)}$ & Spherical & 373 & 113600 & 100 & $8.81 \mathrm{E} 8$ & 0.95 \\
\hline $\mathrm{ECa}^{(2)}$ & Gaussian & 539 & 5.79 & 2.33 & 0.08 & 0.99 \\
\hline $\mathrm{MC}^{(3)}$ & Linear with Sill & 129 & 1.43 & 0.01 & 0.02 & 0.97 \\
\hline $\mathrm{CS}^{(4)}$ & Gaussian & 664 & 18.91 & 1.00 & 2.92 & 0.97 \\
\hline $\mathrm{FS}^{(5)}$ & Gaussian & 529 & 50.60 & 4.80 & 25.1 & 0.98 \\
\hline$S^{(6)}$ & Exponential & 117 & 22.87 & 11.43 & 6.20 & 0.86 \\
\hline $\mathrm{CC}^{(7)}$ & Exponential & 295 & 99.16 & 20.83 & 7.87 & 0.95 \\
\hline
\end{tabular}

${ }^{1}$ ); ${ }^{7}$ Clay (dag kg ${ }^{-1}$ ); ${ }^{8}$ Range (m); ${ }^{9}$ Sill; ${ }^{10}$ Nugget effect; ${ }^{11}$ Spatial dependence index; ${ }^{12}$ Residual sum of squares; ${ }^{13}$ Coefficient of determination.

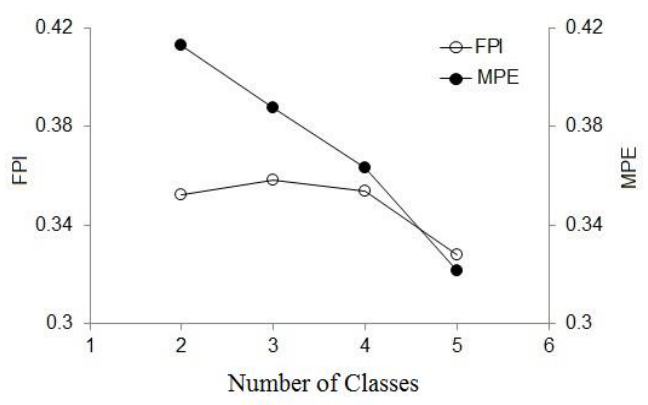

(A)

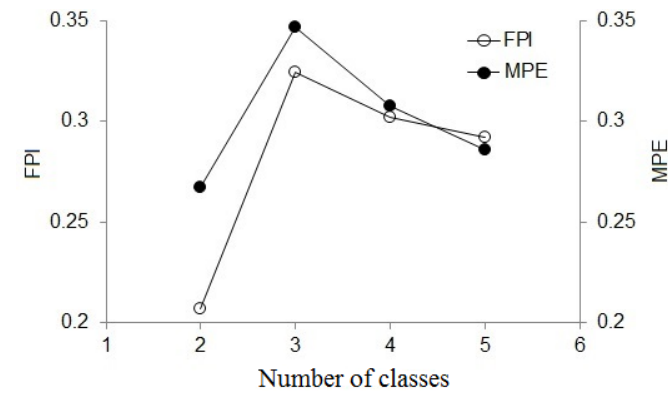

(B)

Fig 3. Fuzzy Performance Index (FPI) and Modified Partition Entropy (MEP) calculated for the management zone from soybean yield (A) and apparent soil electrical conductivity (B; ECa).

Table 4. Kappa coefficients between the management zone map based on the yield data and that based on ECa (B), Coarse sand (C), Fine sand (D), Silt (E), Clay (F) and combinations among them.

\begin{tabular}{|c|c|c|c|c|}
\hline \multirow{2}{*}{ Attributes } & \multicolumn{4}{|c|}{ Number of zones } \\
\hline & 2 & 3 & 4 & 5 \\
\hline $\mathrm{ECa}(\mathrm{B})^{1}$ & $0.30^{\mathrm{a}}$ & $0.14^{\mathrm{c}}$ & $0.13^{\mathrm{c}}$ & $0.08^{\mathrm{c}}$ \\
\hline Coarse sand (C) & Ns & $0.11^{\mathrm{c}}$ & $0.12^{\mathrm{c}}$ & $0.09^{\mathrm{c}}$ \\
\hline Fine sand (D) & Ns & $0.09^{c}$ & $0.06^{\mathrm{d}}$ & $0.13^{\mathrm{c}}$ \\
\hline Silt (E) & Ns & $0.26^{\mathrm{a}}$ & $0.19^{b}$ & $0.16^{\mathrm{b}}$ \\
\hline Clay $(\mathrm{F})$ & Ns & $0.28^{\mathrm{a}}$ & $0.13^{\mathrm{c}}$ & $0.18^{\mathrm{b}}$ \\
\hline $\mathrm{BC}^{2}$ & Ns & $0.09^{c}$ & $0.08^{\mathrm{c}}$ & $0.10^{\mathrm{c}}$ \\
\hline $\mathrm{BD}$ & Ns & $0.09^{c}$ & $0.08^{c}$ & $0.11^{\mathrm{c}}$ \\
\hline $\mathrm{BE}$ & Ns & $0.14^{\mathrm{c}}$ & $0.17^{\mathrm{b}}$ & $0.19^{b}$ \\
\hline $\mathrm{BF}$ & $0.19^{\mathrm{b}}$ & $0.11^{\mathrm{c}}$ & $0.18^{\mathrm{b}}$ & $0.19^{\mathrm{b}}$ \\
\hline $\mathrm{CD}$ & Ns & $0.11^{\mathrm{c}}$ & $0.10^{\mathrm{c}}$ & $0.11^{\mathrm{c}}$ \\
\hline $\mathrm{CE}$ & Ns & $0.12^{\mathrm{c}}$ & $0.15^{\mathrm{b}}$ & $0.21^{\mathrm{a}}$ \\
\hline $\mathrm{CF}$ & Ns & $0.12^{\mathrm{c}}$ & $0.14^{\mathrm{c}}$ & $0.18^{\mathrm{b}}$ \\
\hline $\mathrm{DE}$ & Ns & $0.10^{\mathrm{c}}$ & $0.16^{\mathrm{b}}$ & $0.21^{\mathrm{a}}$ \\
\hline DF & Ns & $0.28^{\mathrm{a}}$ & $0.24^{\mathrm{a}}$ & $0.19^{\mathrm{b}}$ \\
\hline $\mathrm{EF}$ & Ns & $0.18^{\mathrm{b}}$ & $0.19^{b}$ & $0.19^{b}$ \\
\hline $\mathrm{BCD}$ & Ns & $0.08^{\mathrm{c}}$ & $0.08^{c}$ & $0.11^{\mathrm{c}}$ \\
\hline BCE & Ns & $0.16^{\mathrm{b}}$ & $0.12^{\mathrm{c}}$ & $0.19^{\mathrm{b}}$ \\
\hline $\mathrm{BCF}$ & Ns & $0.11^{\mathrm{c}}$ & $0.17^{\mathrm{b}}$ & $0.18^{\mathrm{b}}$ \\
\hline $\mathrm{BDE}$ & Ns & $0.15^{\mathrm{b}}$ & $0.12^{c}$ & $0.21^{\mathrm{a}}$ \\
\hline $\mathrm{BDF}$ & Ns & $0.11^{\mathrm{c}}$ & $0.19^{b}$ & $0.14^{\mathrm{c}}$ \\
\hline $\mathrm{BEF}$ & Ns & $0.20^{\mathrm{a}}$ & $0.11^{\mathrm{c}}$ & $0.19^{b}$ \\
\hline CDE & Ns & Ns & $0.15^{\mathrm{b}}$ & $0.22^{\mathrm{a}}$ \\
\hline $\mathrm{CDF}$ & Ns & $0.28^{\mathrm{a}}$ & $0.19^{b}$ & $0.19^{b}$ \\
\hline CEF & Ns & $0.16^{\mathrm{b}}$ & $0.19^{\mathrm{b}}$ & $0.19^{\mathrm{b}}$ \\
\hline DEF & Ns & $0.17^{\mathrm{b}}$ & $0.19^{b}$ & $0.22^{\mathrm{a}}$ \\
\hline BCDE & $0.11^{\mathrm{c}}$ & $0.17^{\mathrm{b}}$ & $0.13^{\mathrm{c}}$ & $0.21^{\mathrm{a}}$ \\
\hline $\mathrm{BCDF}$ & $0.15^{\mathrm{b}}$ & $0.11^{\mathrm{c}}$ & $0.08^{c}$ & $0.19^{b}$ \\
\hline BCEF & Ns & $0.20^{\mathrm{a}}$ & $0.12^{\mathrm{c}}$ & $0.19^{b}$ \\
\hline BDEF & Ns & $0.20^{\mathrm{a}}$ & $0.11^{\mathrm{c}}$ & $0.21^{\mathrm{a}}$ \\
\hline CDEF & Ns & $0.16^{\mathrm{b}}$ & $0.19^{b}$ & $0.19^{b}$ \\
\hline BCDEF & Ns & $0.20^{\mathrm{a}}$ & $0.11^{\mathrm{c}}$ & Ns \\
\hline
\end{tabular}




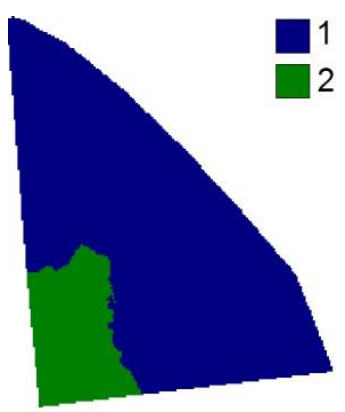

Fig 4. Delineation of two management zones (1 and 2) suggested by the zone map generated using soil ECa data.

values for the delineation of management zones from ECa were reported by Valente et al. (2012) with FPI and MPE values of 0.22 and 0.27 , respectively. The authors obtained these indices by grouping the variable ECa into two classes, these studies corroborate our findings.

The cluster analysis delineates two distinct management zones with limits that can be easily located in the field. The use of these management zones does not require high technological expertise in the farm (Fig4). It is important to emphasize that these classes of the map are derived from the $\mathrm{ECa}$ map, which is quick and inexpensive to produce, thereby, reducing the need for costly laboratory tests.

The use of ECa to stratify the area into management zones is related to the factors that are associated with some soil attributes, which are related to crop yield, as previously reported. King et al. (2005) explained that the measured ECa values are directly dependent on some soil attributes, whereas the yield reflects the integrated response of the crop to the most important soil attributes for its growth. Similarly, Netto et al. (2007) found a significant positive correlation between the apparent electrical conductivity and the concentration of salts in the soil.

Electromagnetic techniques have the advantages of being (i) non-invasive, (ii) able to rapidly obtain a large number of measurements at the scale studied and (iii) able to provide reproducible measurements (Besson et al., 2010). Considering the potential of ECa in discriminating the soil attributes related to soybean yield, it is convenient to use ECa in delineating management zones for optimal fertilizer application. Moreover, ECa measurement is fast and inexpensive, which increases its potential utility in precision agriculture. Studies related to soil fertility management based on management zones derived from ECa data and their influences on crop yield are therefore needed for validation of this technique.

\section{Materials and Methods}

\section{Study area description}

The work was conducted on a farm located in the municipality of Ponta Porã, Mato Grosso doSul, Brazil $\left(22^{\circ}\right.$ $32^{\prime} 09^{\prime \prime}$ South latitude and $55^{\circ} 43^{\prime} 33^{\prime \prime}$ 'West longitude). A 47 ha field was used in which soybean (Glycine max) and corn (Zea mays) are cultivated in a crop succession system using no-till practices for last 12 years. The soil is classified as a clayey Oxisol (Embrapa, 2006).

\section{Experimental procedure}

For the data collection, in February 2012, we used grid sampling with 160 points and $50 \mathrm{~m}$ spacing (Fig5). Soil samples were collected at 80 points by a composite soil sampling of five sub-samples each taken in the area surrounding the sampling point, at a soil depth of 0.00 to 0.20 $\mathrm{m}$. Each sampling point was located using a Garmin GPS receiver, GPSMAP 62. The samples were sent to the Soil Laboratory of the Federal University of Viçosa for the determination of the moisture content and texture analysis, including the clay, silt, fine sand and coarse sand contents. The texture analysis was performed using the pipette method (Ruiz, 2005). The thermogravimetric method was used for the determination of the moisture content. At each sampling point, the apparent soil ECa was measured using the electrical resistivity method. A portable conductivity meter ERM-02 (Landviser ${ }^{\circledR}$ LandMapper ${ }^{\circledR}$, place) device was used to measure the ECa with four electrodes arranged for measuring the soil layer for a depth of $0-0.20 \mathrm{~m}$. This device applies an electric current to the external electrodes and measures the potential difference in the internal electrodes. The electrode assembly was used in the Wenner Matrix configuration (Corwin and Hedrickx, 2002; Corwin and Lesh, 2003). The soybean yield maps were obtained by collecting the plants at each sampling point in one linear meter along three rows, representing an area of $1.35 \mathrm{~m}^{2}$. The plants collected were placed in bags and then threshed, and the grains were then weighed. The moisture content of the grain mass of each sample was determined using the capacitance method. The grain mass was corrected to a grain moisture of $13 \%$ wet basis. The corrected values of mass $(\mathrm{kg})$ were divided by the area (ha) of the collection, thus obtaining yield in $\mathrm{kg} \mathrm{ha}^{-1}$.

\section{Statistical analysis}

The results of soil texture analysis, the ECa readings, and the crop yield were subjected to descriptive statistical analysis and then to spatial dependence analysis. The spatial dependence was evaluated using variogram adjustments, assuming the stationarity of the intrinsic hypothesis, as defined in Equation 1.

$$
\hat{y}(h)=\frac{1}{2 N(h)} \sum_{i=1}^{N(h)}\left[Z\left(x_{i}\right)-Z\left(x_{i+h}\right)\right]^{2}
$$

where

$\hat{\gamma}(h)=$ Semivariance as a function of the distance $(\mathrm{h})$ between pairs of points;

$\mathrm{h}=$ Distance between pairs of points, $\mathrm{m}$;

$\mathrm{N}(\mathrm{h})=$ Number of experimental pairs of observations $\mathrm{Z}\left(\mathrm{x}_{\mathrm{i}}\right)$ and $\mathrm{Z}\left(\mathrm{x}_{\mathrm{i}+\mathrm{h}}\right)$ separated by a distance $\mathrm{h}$.

The following variogram models were tested: the linear model with sill, Gaussian, spherical and exponential models. 


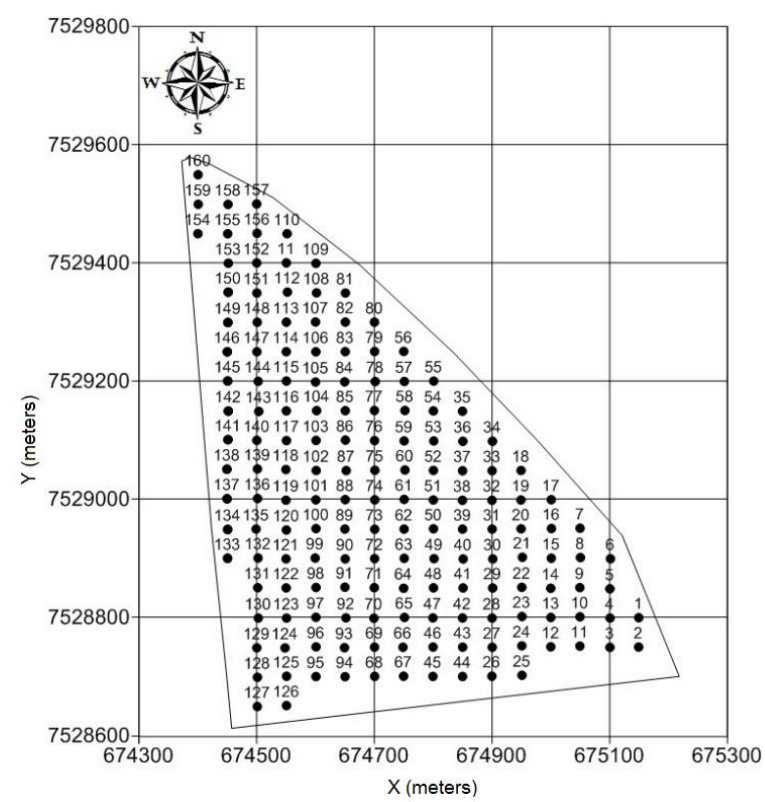

Fig 5. Representative map of the study area and of the 160 sampling points used as a reference for data collection. UTM Coordinates, Zone 21 South, datum SIRGAS2000.

The model that resulted in the smallest residual sum of squares (RSS) was chosen to represent the theoretical variogram. The following parameters were determined in the analysis: nugget effect $\left(\mathrm{C}_{0}\right)$, sill $\left(\mathrm{C}_{0}+\mathrm{C}\right)$ and range $(\mathrm{A})$.

Once the spatial dependence was analyzed, the thematic map of the soil attributes was obtained by performing ordinary kriging. For the estimates of values in non-sampled locations, the 16 closest neighbors were used with a neighborhood radius equal to the range value found in the variogram adjustment. The analysis of the spatial variability of the soil attributes and crop yield and the generation of management zones were performed using the software KrigMe developed by Valente (2010). The software uses the fuzzy k-means classification algorithm to delimit management zones. The number of management zones that best represented the data cluster was defined as a function of the Fuzziness Performance Index (FPI), which estimates the degree of separation of members into different classes and the Modified Partition Entropy (MPE), which estimates the degree of disorganization created by the number of zones. The indices of the FPI and the MPE can vary between 0 and 1 and thus, the optimal number of management zones occurs when the two indices are minimized (Song et al., 2009).

\section{Management zone delineation}

Firstly, the management zone map was obtained using only the yield data. For other soil attributes (soil texture data and ECa), management zone maps were generated for all possible combinations of these soil attributes. The management zone maps were then compared to the map generated from the yield data. The kappa coefficient (Congalton and Mead, 1983) evaluated the similarity between the maps using a hypothesis test, which compared the reference map (the management zones map generated based on yield) to the other maps. For the estimation of the kappa coefficient, the software first calculates disagreement between the management zone maps generated to produce error matrices. The kappa coefficient is then calculated using these matrices, between the soil management zone maps and its correspondent yield data and with the other soil attribute data.
The value of the kappa coefficient indicates the agreement between the generated maps and the reference map. Kappa values equal to zero indicate that the maps are different. The similarity between the maps tends to increase as the kappa coefficient approaches one, indicating that the maps are identical (Hudson and Ramm, 1987). The soil management zone map that best represented the yield data was selected by the following criteria: 1) Maps with significant kappa coefficients using Z-test; 2) for the same kappa coefficients, the map with the lowest number of management zones was adopted; and 3) after setting the number of management zones, the kappa coefficients for each group of soil attributes were ranked, and the management zone map with the highest kappa value significantly different from zero was considered as the best fit.

\section{Conclusion}

The delineation of management zones based on the apparent soil electrical conductivity had the highest kappa coefficient for the yield of soybean in the area under the study. The study demonstrated the potential of ECa map in precision agriculture. When the management zones are defined on the basis of soil texture analysis, three classes should be considered as the number of classes to obtain larger kappa coefficients for the yield.

\section{Acknowledgements}

The authors thank the National Council for Scientific and Technological Development (CNPq) and the Research Foundation of the State of Minas Gerais (FAPEMIG) for scholarships and financial support for carrying out this study and the São Judas Tadeu Farm for offering the study area and logistics demanded in this work.

\section{References}

Alcântara GR, Reis EF,Queiroz DM (2012)Produtividade de culturas correlacionada com condutividade elétrica aparente de um solo sob plantio direto. Rev Agrotec. 3(2):62-72. 
Alves, SMF, Alcântara GR, Reis EF, Queiroz DM, Valente DSM (2013) Definição de zonas de manejo a partir de mapas de condutividade elétrica e matéria orgânica. Biosc J. 29(1):104-114.

Amado TJC, Pes LZ, Lemainski CL, Schenato RB (2009) Atributos químicos e físicos de latossolos e sua relação com os rendimentos de milho e feijão irrigados. Rev Bras Cienc Solo. 33(4):831-843.

Besson A, Cousin I, Bourennane H, Nicoullaud B, Pasquier C, Richard G, Dorigny A, King D (2010) The spatial and temporal organization of soil water at the field scale as described by electrical resistivity measurements. Eur J Soil Sci. 61:120-132.

Brevik E, Fenton T, Lazari A (2006) Soil electrical conductivity as a function of soil water content and implications for soil mapping. Precis Agric. 7(6):393-404.

Congalton RG, Mead RA (1983) A quantitative method to test for consistency and correctness in photointerpretation. Photogramm Eng Rem S. 49(1):69-74.

Corá JE, Araujo AV, Pereira GT, Beraldo JMG (2004) Variabilidade espacial de atributos do solo para adoção do sistema de agricultura de precisão na cultura de cana-deaçúcar. Rev Bras Cienc Solo.28(6):1013-1021.

Corwin DL, Hendrickx JMH (2002) Electrical Resistivity: Wenner Array. In: SILVA JS Methods of Soil Analysis: Part 4 - Physical Methods, Madison, Wisconsin, USA: SSSA Book Series.

Corwin DL, Lesch SM (2003) Application of Soil Electrical Conductivity to Precision Agriculture: Theory, Principles, and Guidelines. Agron J.95(3):471-471.

Dalchiavon FC, Carvalho MP, Andreotti M, Montanari R (2012) Variabilidade espacial de atributos da fertilidade de um Latossolo Vermelho Distroférrico sob Sistema Plantio Direto. Rev Cienc Agron.43(3):453-461.

EMBRAPA (Empresa Brasileira de Pesquisa Agropecuária) (2006) Sistema brasileiro de classificação de solos,2nd edn. Rio de Janeiro: EMBRAPA-SPI, 306 p.

Fu Q, Wang Z, Qiuxiang J (2010) Delineating soil nutrient management zones based on fuzzy clustering optimized by PSO. Math Comput Model.51(11-12):1299-1305.

Hudson WD, Ramm CW (1987) Correct formulation of the kappa coefficient agreement. Photogramm Eng Rem S.53:421-422.

King J, Dampney P, Lark R, Wheeler H, Bradley R, Mayr T (2005) Mapping potential crop management zones within fields: use of yield-map series and patterns of soil physical properties identified by electromagnetic induction sensing. Precis Agric. 6(2):167-181.

Kitchen NR, Sudduth KA, Myers DB, Drummond ST, Hong SY (2005) Delineating productivity zones on claypan soil fields using apparent soil electrical conductivity. Comput Electron Agr. 46(1-3):285-308.

Machado PLOA, Bernardi ACC, Valencia LIO, Molin JP, Gimenez LM, Silva CA, Andrade AG, Medari BE, Meirelles MSP (2006) Mapeamento da condutividade elétrica e relação com a argila de Latossolo sob plantiodireto. Pesqui Agropecu Bras. 41(6):1023-1031.

McCormick S, Jordan C, Bailey J (2009) Within and between-field spatial variation in soil phosphorus in permanent grassland. Precis Agric. 10(3):262-276.

Molin JP,Castro CN (2008) Establishing management zones using soil electrical conductivity and other soil properties by the fuzzy clustering technique. Sci Agr. 65(6):567-573.

Moral FJ, Terrón JM, Silva JRM (2010) Delineation of management zones using mobile measurements of soil apparent electrical conductivity and multivariate geostatistical techniques. Soil Till Res. 106(2):335-343.
Morari F, Castrignanò A, Pagliarin C (2009) Application of multivariate geostatistics in delineating management zones within a gravelly vineyard using geo-electrical sensors.Comput Electron Agr.68:97-107.

Netto AOA, Gomes CCS, Lins CCV, Barros AC, Campeche LFSM, Blanco FF (2007) Características químicas e salinosodicidade dos solos do perímetro irrigado Califórnia, SE, Brasil. Cienc Rural.37(6):1640-1645.

Rodrigues Junior FA,Vieira LB, Queiroz DM, Santos NT (2011) Geração de zonas de manejo para cafeicultura empregando-se sensor SPAD e análise foliar. Rev BrasEng AgricAmb. 15(8):778-787.

Rodríguez-Pérez JR, Plant RE, Lambert JJ, Smart DR (2011) Using apparent soil electrical conductivity (ECa) to characterize vineyard soils of high clay content. Precis Agric. 12(6):775-794.

RuizHA (2005) Incremento da exatidão da análise granulométrica do solo por meio da coleta da suspensão (silte + argila). Rev Bras Cienc Solo. 29:297-300.

Serrano JM, Peça JO, Silva JR, Shahidian S (2010) Medição e mapeamento da condutividade eléctrica aparente do solo em pastagens. Rev Cienc Agrar. 33(2):5-14.

Song X, Wang J, Huang W, Liu L, Yan G, Pu R (2009) The delineation of agricultural management zones with high resolution remotely sensed data. Precis Agric. 10(6):471487.

Souza ZM, Marques Júnior J, Pereira GT, Barbieri DM (2004) Variabilidade espacial da textura de um Latossolo Vermelho Amarelo eutroférrico sob cultivo de cana-deaçúcar. Eng Agric. 24(2):309-319.

Valente DSM (2010) Desenvolvimento de um sistema de apoio à decisão para definir zonas de manejo em cafeicultura de precisão. Tese (Doutorado em Engenharia Agrícola) - Departamento de Engenharia Agrícola, Universidade Federal de Viçosa, Viçosa, 122p.

Valente DSM, Queiroz DM, Pinto FAC, Santos NT, Santos FL (2012) The relationship between apparent soil electrical conductivity and soil properties. Rev Cienc Agron. 43(4):683-690.

Zanão Júnior LA, Lana RMQ, Carvalho-Zanão MP, Guimarães EC (2010) Variabilidade espacial de atributos químicos em diferentes profundidades em um latossolo em sistema de plantio direto. Rev Ceres. 57(3):429-438.

Zanão Júnior LA, Lana RMQ, Guimarães EC (2007) Variabilidade espacial do $\mathrm{pH}$, teores de matéria orgânica e micronutrientes em profundidade em um Latossolo Vermelho sob semeadura direta. Cienc Rural. 37(4):10001007.

Zhang X, Shi L, Jia X, Seielstad G, Helgason C (2010) Zone mapping application for precision-farming: a decision support tool for variable rate application. PrecisAgric. 11(2):103-114 